\title{
How Past Vicariant Events Can Explain the Atlantic Forest Biodiversity?
}

\author{
Gisele Pires Mendonça Dantas ${ }^{1}$, \\ Gustavo Sebastián Cabanne ${ }^{3}$ and Fabrício Rodrigues Santos ${ }^{2}$ \\ ${ }^{1}$ Instituto de Biociências - Universidade de São Paulo- Rua do Matão, \\ Cidade Universitária, São Paulo, SP \\ ${ }^{2}$ Instituto de Ciências Biológicas- Universidade Federal de Minas Gerais- Av. \\ Antônio Carlos, Belo Horizonte, MG \\ ${ }^{3}$ Museo Argentino de Ciencias Naturales, "Bernadino Rivadavia", \\ Av. Angel Gallardo 470, Buenos Aires \\ 1,2Brazil \\ ${ }^{3}$ Argentina
}

\section{Introduction}

Biodiversity is a wide term that includes all the hierarchy of life in the Earth. However, this word refers to the whole biological diversity: ecosystem diversity, species diversity and genetic diversity. Those three levels of diversity are melt one in another. The basal level involves genetic diversity that includes variation within and among individuals that are grouped in populations. In the next level, populations may differentiate due to mutations, genetic drift and different environmental pressures into distinct species. Finally, ecosystems are characterized by different assemblages of species (Hunter, 1996).

The biological communities observed today were formed along millions of years, although most of those biomes have been already affected by human activity, including many severally endangered regions of the world (Primack \& Rodrigues, 2001). Some human activities that affect natural environments are as deforestation, coast occupation, overhunting and introduction of exotic species. Thus, nowadays, the great challenge for conservation of natural systems is to conciliate human activities and conservation. The discipline of conservation biology emerge as answer to this crisis, with multidisciplinary approaches that aim to investigate the human impacts on natural populations, biological communities and ecosystems; to developed practice to prevent the environmental degradation and species extinction, restoration of ecosystems and reintroduction of populations, to establish sustainable relationship between human communities and ecosystems (Rozzi et al., 1998). However, all remaining ecosystems have been previously affected by multiple natural impacts such as climatic changes during the Pleistocene. Then, conservation biology also aims to discriminate between impacts due to natural events from those due to anthropogenic causes affecting current biodiversity distribution.

Biogeography, community ecology and population genetics attempt to describe how biological diversity is spatially distributed at different geographic scales (Miller et al. 
2010, Diniz-Filho et al. 2008). Into this context, the molecular biology provides the tools to further investigate phylogenetic relationships among organisms, which can be associated with geographical distribution. With technological advances, the molecular markers have been increasingly applied to access genetic partitions among geographically isolated populations. The relationship between gene genealogies and geography can be used to estimate historical processes that can be responsible for contemporary geographic distributions of individuals and species. This new discipline, the phylogeography, is enabling us to understand processes of diversification, and to reconstruct the historical relationships considering explicit biogeographic hypotheses (Smith \& Patton 1993, Patton et al. 1994).

One of the oldest and likely most recognized biodiversity patterns is the latitudinal gradient of species richness (Rosenzweig 1995, Miller et al. 2010). The marked difference in biodiversity richness from regions of high and low latitudes is well documented across distinct taxonomic levels and constitutes a widely recognized biogeographical pattern (D’Horta et al. 2011, Willig et al. 2003). The description of geologic, biogeographic and genetic patterns along tropical ecosystems helps us to better understand the differential effects of evolutionary history of low latitudes in the biodiversity dynamics. In this context, the objective of this chapter was to review the hypotheses of diversification proposed to explain the current biodiversity distribution observed in Brazilian Atlantic Forest. We present here each hypothesis and the different studies supporting or rejecting them.

The Atlantic forest is distributed along eastern and southwestern Brazil, eastern Paraguay, and north-eastern Argentina (Gusmão Câmara, 2003). The Brazilian Atlantic Rain Forest originally presented an area of 1.1 million $\mathrm{km}^{2}$ and covered a large extension of the coast. Given this large geographic extent, the Atlantic Forest is floristically diverse with severe regional forms of rainforest (ombrophilous) and semi-deciduos forest, depending on rainfall regimes (Oliveira-Filho \& Fontes, 2000) (Figure 1). Nowadays, this biome is considered one of the most important conservation hotspots of the World, because of its high levels of endemism and degradation. For example, although near 200 endemic species of birds are reported there, only 5\% of its original area remain (Myers et al., 2000). The last estimates account for approximately 20.000 vascular plant species and over 2.300 vertebrate species, half of them being endemic and about 150 with threatened status (Conservation International do Brasil et al., 2000).Furthermore, most of the remaining forested areas are located in regions of steep topography, where agriculture and cattle ranching are not economically viable.

The Atlantic forest biota is probably the result of a complex evolutionary history; however, the processes that shaped it are not well known (Mustrangi \& Patton, 1997; Costa et al., 2000; Smith \& Patton, 2001; Pellegrino et al., 2005). The knowledge of these evolutionary processes is extremely important for conservation purposes (Moritz, 2002). Among the hypothesis for diversification in Atlantic Forest, the models of Pleistocene refuges, gradient hypothesis; rivers as barriers and orogeny changes have been well discussed. All hypotheses are based in some provisional reductions gene flow among populations, which promoted divergence in allopatry, when the populations became different because they were somehow geographically isolated.

In the following section we discuss each hypothesis. 


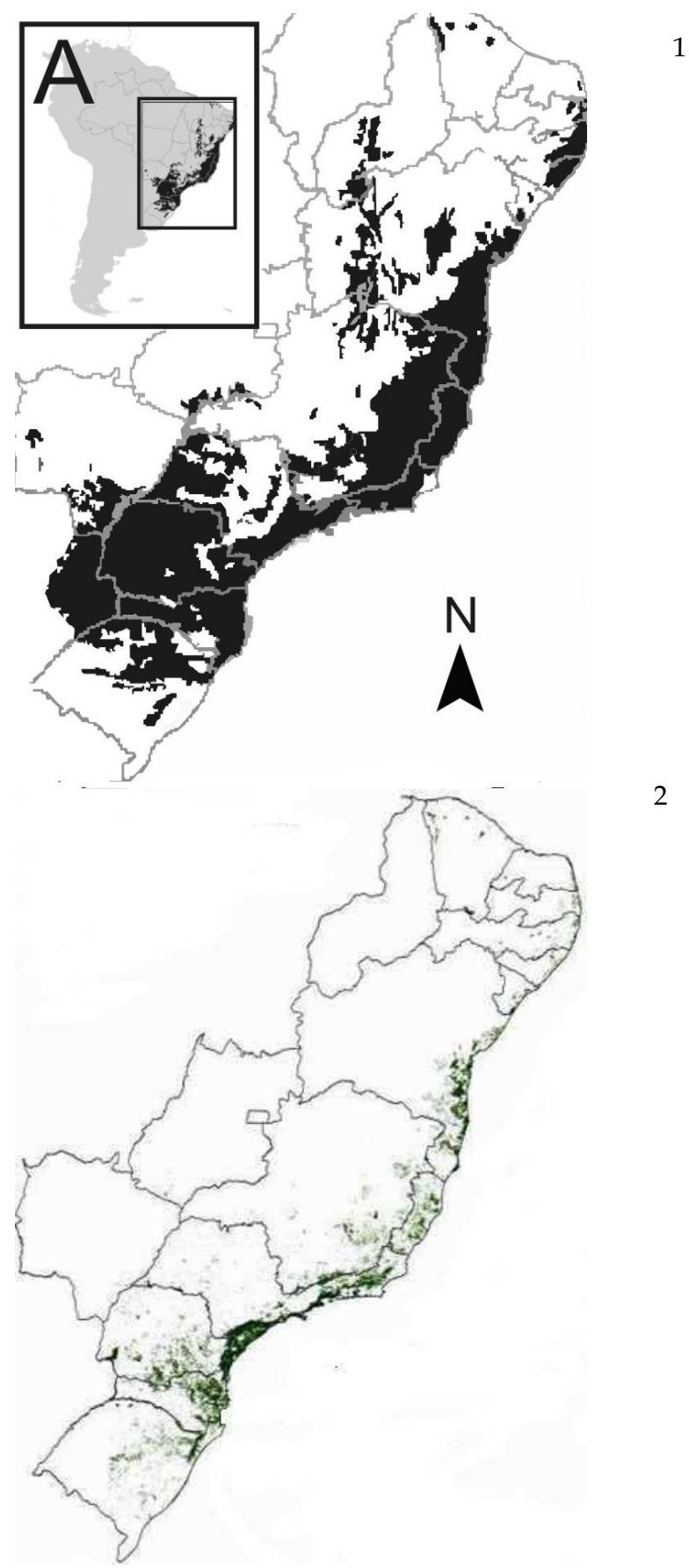

Fig. 1. Original (1) and remain (2) spatial distribution of Brazilian Atlantic Forest . 


\section{Pleistocene refuges}

The refuges theory is one of the most discussed models of diversification to explain the origin of the diversity of the Atlantic forest. In the Neotropics, the refuge theory was originally proposed to explain speciation during the Pleistocene mainly in the Amazon basin (Haffer, 1969; Vanzolini \& Williams, 1970; Brown \& Ab'Saber, 1979; Haffer \& Prance, 2001). This theory proposes that during the glaciations the rainforests were reduced to refuges isolated by open areas, and that organisms isolated in these refuges could have diverged and originated new lineages. Then, in the next interglacial period, the forest expanded and the new clades would be in secondary contact. Brown and $\mathrm{Ab}^{\prime}$ Saber (1979) proposed that open areas dominated the Atlantic forest's landscape during the maximum of Late Pleistocene glaciations, suggesting that the refuge theory can be important to understand the biological diversification of the biome. Taxa may have evolved in allopatry within refuges (rainforest relicts) due to evolutionary factors as genetic drift and divergent selection.

The refuges hypothesis predicts to find evidence of high species endemism and high genetic diversity in the areas with high stability or forest in the past (refugial zones) and, in contrast, lower diversity, lower endemism and molecular signatures of recent range expansion within species in unstable, recently recolonized regions (non-refugial areas) (Carnaval \& Moritz 2008). Moritz et al. (2000) and Thomé et al. (2010) affirmed the refuges hypothesis still need to consider additional predictions: the presence of sister taxa in adjacent refugia, secondary contact zones between refugia and range expansion out of refugia area refuges areas.

Carnaval \& Moritz (2008) used climatic and forest distribution models and predicted the existence of a large and stable forest refuge in the state of Bahia, in the northeast of Brazil, and smaller refuges located along the Brazilian coast, one area north of the Paraiba river, called Pernambuco refuge, and possibly many small patches south of the Doce River and severe forest contraction south of the São Paulo state (Figure 2). Thomé et al. (2010) also used paleoclimatic modeling to suggest five stable areas in Atlantic Forest to Rhinella crucifer (toad) (1) the coastal region of north eastern Brazil, ranging from Alagoas to Rio Grande do Norte, called Pernambuco region; 2) southeastern Brazil, ranging from Rio de Janeiro to Espírito Santo and eastern Minas Gerais; 3) coastal south-southeastern Brazil, ranging from north Santa Catarina to São Paulo (called Serra do Mar); 4) the interior of the Paraná state; and 5) central-north Rio Grande do Sul state and western Santa Catarina state. Thomé et al. (2010) and Carnaval \& Moritz (2008) showed many concordant refuges, with a difference that Tomé et al. (2010) found more areas in south Brazil due likely to specific habitat conditions of Rhinella crucifer (Figure 2).

Many studies have also found the phylogeographic patterns along Atlantic Forest that are compatible with predictions of the refuge hypothesis. For example, D’Horta et al. (2011) observed that in the study of intrapopulation genetic variation of Sclerurus scansor (Rufousbreasted Leaftosser) is compatible with that proposed by refuges hypothesis. They found three groups well defined, one in north of Atlantic Forest (Ceará state), another in central (Bahia, Minas Gerais and north São Paulo State), and a last one the south (Southern São Paulo, Santa Catarina and Rio Grande do Sul State). The estimate of the divergence time between lineages point to events during the middle and late Pleistocene, a period for which there are extensive records documenting change in forest distribution associated with climatic cycles. 
Cabanne et al. (2007) also demonstrated demographic changes in Xyphorhynchus fuscus (Lesser Woodcreeper) consistent with responses to Pleistocene forest contractions and subsequent advances into southern areas of the Atlantic biome in responses to late Quaternary climate change. The same pattern was found to Conopophoga lineata (Rufous Gnateater), which showed data consistent with differentiation in the Pleistocene period (Pessoa, 2008). In some cases, those lineages showed also a secondary contact due to recent expansion in the Holocene period, as it has been found between south Minas Gerais State and North São Paulo, for Xynphorhynchus fuscus (Lesser Woodcreeper)(Cabanne et al. 2007) and Conopophoga lineata (Rufous Gnateater) (Pessoa 2008) and Sclerurus scansor (Rufousbreasted Leaftosser) (D’Horta et al. 2011).

Martins et al. (2009) also found two phylogroups in Desmodus rotundus (common vampire bat) whose estimate divergence times fall within the Pleistocene epoch, suggesting this bat is susceptible to forest fragmentation into refuges. Pavan et al. (2010) studied other species of bat Carollia perspicilatta (Short-tailed fruit bat), also found two clades whose dating corroborated the vicariant event occurring in the Pleistocene, following by recent population expansion. Moraes-Barros et al. (2006) inferred two main phylogeographic groups exist in the Atlantic forest for Bradipus torquatus and Bradipus variegatus (Sloth) representing north (Southeastern region of Bahia State north of Minas Gerais) and south (Esplírito Santo and São Paulo)

The difference between clades north and south observed in several Atlantic Forest species, led to the discussion about the influence of latitudinal gradient. The Atlantic Forest covers the $2^{\circ}$ to $30^{\circ} \mathrm{S}$ alongside the Brazilian coast, consequently presents significant differences in temperature and humidity, which in the past could have affected the number of refuges. The influence of the latitudinal gradient affecting the biodiversity is one of the oldest and most recognized patterns associated to species richness (Rosenzweig 1995). Because of the strong historical effect that Pleistocene era glaciers had on the biogeography of higher latitudes, it is perhaps not surprising that post-glacial expansion is usually considered primarily responsible for the observed genetic diversity patterns (Hewitt 1996, Miller et al. 2010). Vellend (2003) and Vellend and Geber (2005) noted that the same biogeographic conditions favorable to high species richness within community (i.e. high immigration rates and low extinction rates) should promote high genetic diversity within the species comprising that community (Miller et al. 2010). Many studies focused on temperate zone organisms have suggested that latitudinal patterns of within population genetic diversity are most likely due to a history of post-glacial poleward habitat expansion (Miller et al. 2010). The latitudinal biodiversity gradient may reflect the distinct influence of Pleistocene glacial and interglacial cycles in the geographic landscape (Hewitt 2004). Because of the strong historical effect that Pleistocene glaciers had on the biogeography of higher latitudes, it is perhaps not surprising that post-glacial expansion is usually considered primarily responsible for the observed genetic diversity patterns (Hewitt 1996, Miller et al. 2010). In accordance with D’Horta et al. (2011) the latitudinal gradient hypothesis makes some explicit predictions: 1) populations form higher latitudes experienced more pronounced change in their effective population sizes and therefore exhibit signatures of recent demographic expansion and a lower genetic structure; 2) populations from lower latitudes experienced smaller or no changes in effective sizes, thus presenting higher diversity and genetic structure. Carnaval et al. (2009) observed that amphibians from Atlantic Forest showed higher levels of genetic diversity and structure of population in lower than higher latitudes. Some studies of mammals, birds and reptiles have found latitudinal 
differentiation along the Brazilian Atlantic Forest, and showed an expansion signal in lower latitudes (Pavan et al. 2011, Grazziotion et al. 2006, Martins et al. 2009). However, these studies did not report higher genetic diversity in northern population (lower latitudes), as it would be expected under gradient hypothesis.
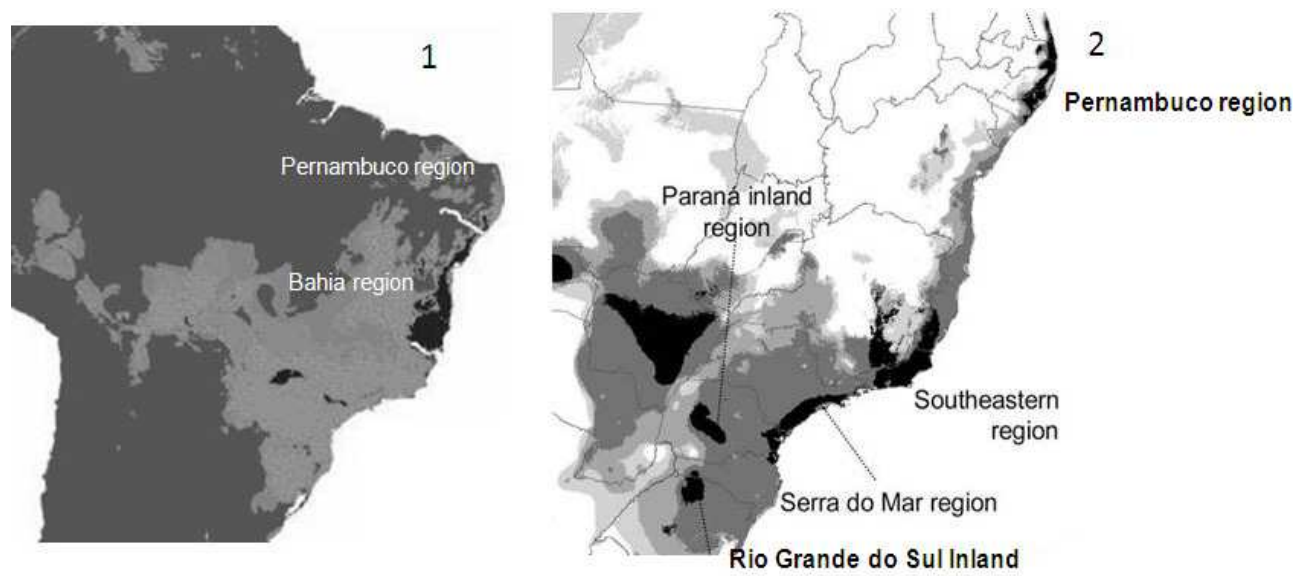

Fig. 2. Summary maps of historically stable areas for the Atlantic forest definitions, obtained by(1) Carnaval and Moritz (2008) summing across BIOCLIM and MAXENT output grids for forest absence/presence under current and (2) Thomé et al. (2010) models of habitat distribution for current time, last interglacial period (LIG), last glacial maximum period (LGM),

\section{Neotectonic hypothesis}

The Atlantic margin of the South American plate is tectonically passive (see Thomé et al. 2010), although little changes occur, causing faults and fractures and consequently affect dated sedimentary deposits, regional uplifts consequently remodeling the landscape (Ricommini \& Assumpção 1999). In the Brazilian Atlantic Forest many changes may have been caused by the uplift of the coastal Brazilian mountains (Serra do Mar). Those events possibly interrupted precipitation in southeastern Brazil by the early Pliocene at about 5.6 $\mathrm{Ma}$ and therefore altered the distribution of humid and dry habitats. This period coincides with the transition from tropical humid to semiarid or arid conditions described by some authors (Simpson 1979; Vasconcelos et al. 1992). This orogenic process deeply changed the geomorphologic and climatic conditions of south and southeast areas of Brazil, and consequently fragmented Brazilian Atlantic Forest with drier areas (Grazziotini et al. 2006). The palynological record of the Quartenary showed that between 33,000 and 25,000 years ago, the central Brazilian region was moister than today and was covered by rainforest (Ledru 1993), and during the last glaciation (18,000-12,000 years ago) the present day corridor of xeric vegetation was covered by extensive woodland (Prado \& Gibbs 1993, Costa et al. 2003). It is believed that during drier periods, forest formations 
were more likely to occur in mountain areas, because of the higher pluviometric level resulting from orographic effect. Such phenomenon is currently observed in north-eastern region of Brazil, where the occurrence of humid forests is strictly associated with areas of mountain ridges (D’Horta et al. 2011).

Mountain chains often delimit Atlantic Forest distribution, but few studies have established geomorphological events as promoter of allopatric diversification in this biome (Thomé et al. 2010). Neotectonic activity has significantly remodeled the landscape of eastern Brazil during the Quaternary, confounding the signatures of isolation mechanisms along this Tertiary-Quaternary time scale. Thomé et al. (2010) found that the distinct phylogroups concordant with neotectonic barriers in Guapiara lineament and the Cubatão Shear zone in the São Paulo State, both including recent superficies ruptures (Ricommni and Assumpção, 1999). Although, the tectonic events in the region occupied by Brazilian Atlantic Forest are still poorly understood, they may be an alternative explanation to observed patterns.

\section{Riverine barriers}

The rivers can play an important role in biological diversification as they may act as primary or secondary barriers to gene flow and may have been important to model the current biota distribution. Siedchlang et al. (2010) suggest that the São Francisco River was an important barrier to Calyptommatus (lizards), allowing speciation on opposite margins of the river, being responsible to present distribution of $C$. sinebrachiatus and C. leiolepis, as well as that of C. nicterus and C. leiolepis, which occurred in adjacent banks on opposite margins. Thomé et al. (2010) observed that Rhinella crucifier group presents divergent lineages spatially concordant with Doce River systems and refute the refuges model to diversification this group. Also, Lacerda et al. (2007) presented genetic data that suggested a role of the Jequitinhonha river and Doce river for separating populations of passeriformes Thamnophilus ambiguous (Sooretama). Pellegrino et al. (2005) show also that the genetic structure of lizards of the Gymnodactylus darwinii complex coincides with the river system in the northern regions of the Brazilian Atlantic Forest and that major coastal rivers in this region may have played a key role in its diversification

On the other hand, D’Horta et al. (2011) suggested for Sclerurus scansor that tectonic activity associated with the Paraiba Valley can be congruent with the scenario that the river was important for the secondary contact of lineages of the south and central of Atlantic Forest, but not for the origin of these lineages due to phylogeography rupture, because the divergence time is much more recent (middle/late Pleistocene). This hypothesis of secondary contact among lineages is corroborated by Cabanne et al. (2007) and Pessoa (2008), who also suggested Paraíba do Sul Valley as contact region of divergent mitochondrial lineages from Xyphorhynchus fuscus and Conopophoga lineata. Furthermore, in both margins of the Paranapanema river were also found two phylogroups of Bothrops jararaca (Grazziotin et al. 2006).

In summary, the riverine systems seem important to differentiation between lineages and species, thus, are relevant to consider in the evolutionary processes related to the Atlantic Forest diversification, mainly the São Francisco, Jequitinhonha, Doce and Paranapanema (Fig 3). 


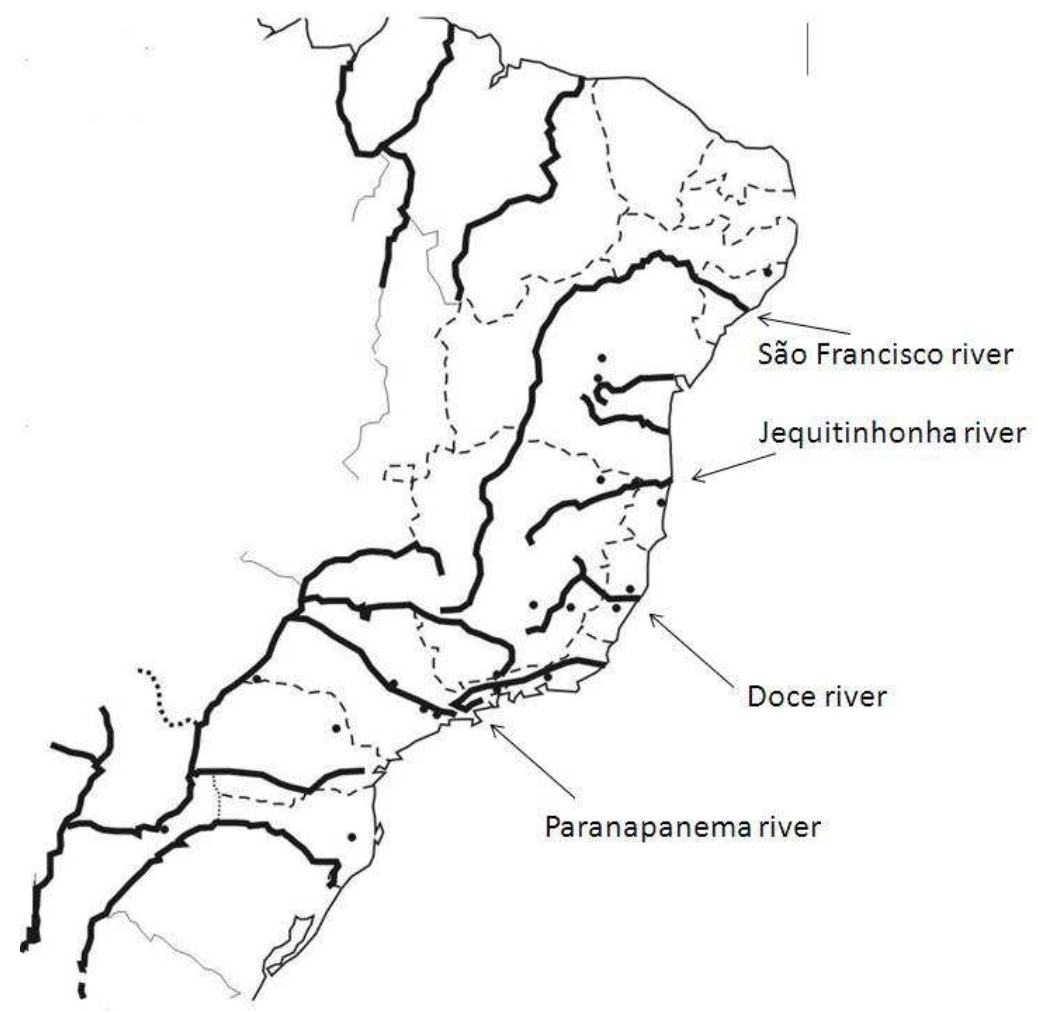

Fig. 3. Localization of mainly rivers that influence the distribution of species at Brazilian Atlantic Forest.

\section{Gradient hypothesis}

The Atlantic Forest is surrounded by dry forests and forested savannas (Cerrado). Because of the existence of a gradual transition from humid forest to those drier biomes, many organisms associated to humid forests are also found intermingled in the open biomes. Each region, the Atlantic forest and the neighboring regions, present different characteristics, and therefore it is expected to find differential selective regimes that could make organisms to diverge between regions. This hypothesis is known as the ecological gradient hypothesis. Also, there are different types of forests within the Atlantic Forest that could imply differential selective regimes. Even though this scenario is very plausible, few studies addressed the problem of divergence across ecological gradients in this biome. For example, Lara et al. (2005) mentions that the occurence of species of tree rat Phyllomys and of spiny rat Trinomys is associated with vegetation types and with humidity gradients indicate that evolution across gradients may be important. Bird species show distributed in different zone of humidity and temperature across forest types in the Atlantic forest with, which could suggest and important role of environmental gradients in their evolution. So far only one study addressed the problem of evolution across gradients in the Atlantic forest. Cabanne et al (in press) studied whether the plumage color in Dendrocolaptes platyrostris was 
related to change by drift in different populations historically isolated, or by selective change in different forest types. They found that the plumage variation was related to different forest types and not to historically isolated lineages, suggesting an important role of selection. D. platyrostris at the open vegetation corridor was lighter and less streaked than at the forest habitat, a morph which is suggested to be an adaptation of woodcreepers for habitats with high luminosity levels, as are forests at the open vegetation corridor (Marantz, 1997; Willis, 1992). On the other hand, rainforest individuals are darker and more streaked, what is considered to be an adaptation to live in low luminosity and very humid conditions (Marantz, 1997; Willis, 1992; Zink \& Remsen, 1986).

\begin{tabular}{|c|c|c|c|c|c|}
\hline Era & Period & Epoch & MYA & Event & Reference \\
\hline \multirow{15}{*}{ 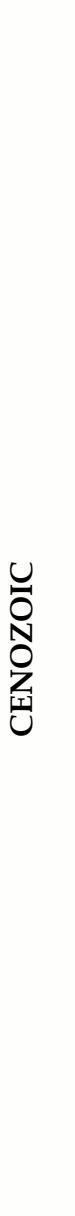 } & \multirow{9}{*}{ 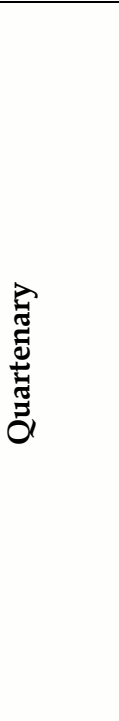 } & Holocene & 0.01 & & \\
\hline & & Pleistocene & 1.8 & $\begin{array}{l}\text { Divergence lineage from Sclerurus } \\
\text { scansor (Passeriformes) }\end{array}$ & $\begin{array}{l}\text { D’Horta et al. } \\
2011\end{array}$ \\
\hline & & & & $\begin{array}{l}\text { Divergence of lineages of } \\
\text { Xyphorhynchus fuscus } \\
\text { (Passeriformes) }\end{array}$ & $\begin{array}{l}\text { Cabanne et al. } \\
2007\end{array}$ \\
\hline & & & & $\begin{array}{l}\text { Divergence of lineages of } \\
\text { Conopophoga lineata (Passeriformes) }\end{array}$ & Pessoa 2008 \\
\hline & & & & $\begin{array}{l}\text { Divergence of lineages from South } \\
\text { the Gymnodectylus darwinii (lizards) }\end{array}$ & $\begin{array}{l}\text { Pellegrino et al. } \\
2005\end{array}$ \\
\hline & & & & $\begin{array}{l}\text { Divergence between lineages of } \\
\text { Carollia perspicillata (bat) }\end{array}$ & $\begin{array}{l}\text { Pavan et al. } \\
2011\end{array}$ \\
\hline & & & & $\begin{array}{l}\text { Divergence of lineages of Rhinella } \\
\text { crucifier center and north Atlantic } \\
\text { Forest (toad) }\end{array}$ & $\begin{array}{l}\text { Thomé et a. } \\
2010\end{array}$ \\
\hline & & & & $\begin{array}{l}\text { Divergence of lineages of Desmodus } \\
\text { rotundus (bat) }\end{array}$ & \begin{tabular}{|l} 
Martins et al. \\
2009
\end{tabular} \\
\hline & & & & $\begin{array}{l}\text { Divergence of lineages of Bradypus } \\
\text { torquatus (Xenarthra) }\end{array}$ & $\begin{array}{l}\text { Moraes-Barros } \\
\text { et al. } 2006\end{array}$ \\
\hline & \multirow{6}{*}{ : } & Pliocene & 5.3 & $\begin{array}{l}\text { Divergence of phylogrops of } \\
\text { Bothrops jararaca (Serpentes) }\end{array}$ & $\begin{array}{l}\text { Grazziotini et } \\
\text { al. } 2006 \text {. }\end{array}$ \\
\hline & & & & $\begin{array}{l}\text { Divergence of lineages of North and } \\
\text { south of Rhinella crucifier (toad) }\end{array}$ & $\begin{array}{l}\text { Thomé et a. } \\
2010\end{array}$ \\
\hline & & & & Uplift Brazilian coast mountain & \\
\hline & & Miocene & 23.0 & Drainage of Parana river & $\begin{array}{l}\text { Grazziotin et al. } \\
2006\end{array}$ \\
\hline & & & & $\begin{array}{l}\text { Neogene } \\
\text { sediments of the Barreiras } \\
\text { Formation Doce River }\end{array}$ & \\
\hline & & & & $\begin{array}{l}\text { Divergence of lineages North and } \\
\text { South Gymnodactylus darwinii } \\
\text { (Lizards) }\end{array}$ & $\begin{array}{l}\text { Pellegrino et al. } \\
2005\end{array}$ \\
\hline
\end{tabular}

Table 1. The geological time scale and the resume of principal studies of Phylogeography in Atlantic Forest 
The open vegetation corridor and its network of gallery forests and dry forests are contiguous with the Atlantic and Amazon forests. The results of Cabanne et al. (in press) supported the idea that the two plumages types of D. platyrostris may have evolved by divergent selection regimes between habitats. There are several other species that occur in both habitats and might present a similar evolutionary story. Puorto et al. (2001) found one clinal morphological variation to Bothrops atrox group, although did not show association with genetic variation, which revealed two clades concordant with division North and South of Forest Atlantic.

\section{Conclusions}

In conclusion, the separation of the northern and southern phylogroups observed at Atlantic Forest endemic species is a pattern found for several taxa, however the discontinuities were observed in distinct zones of the Atlantic Forest. Some discrepancies can be explained by sampling bias, but others can be due to real differences in the dynamics of the species or the associated ecosystem. Anyway, distinct mechanisms have been invoked to explain the breaks, sometimes they were attributed differences are attributed to refuges hypothesis and another times to riverine barriers or tectonic activities. Silva et al. (in press) studied the panbiogeographic nodes in Atlantic Forest found six of the seven nodes found one node (Pernambuco) in North AF, two nodes (Bahia and Espírito Santo) are in Central AF, and three nodes (São Paulo, Paraná and Santa Catarina) correspond to South AF and concluded that the pattern of latitudinal subdivision of taxa distributions has originated at least since the Miocene and is more complex than previously thought. The endemism areas are concordant with the stability areas proposal for Atlantic Forest, the great part of studies show differentiation between lineages in Pleistocene Epoch (Table 1). Due to the complexity of the geomorphological and ecological features of the Atlantic Forest, and the intrinsic complexity of the ecophysiology of the Atlantic Forest organisms, it seems too simplistic to imagine that one single diversification mechanism can explain the origin of the current biogeographical patterns exhibit by Atlantic Forest species (D’Horta et al. 2011). A realist scrutiny of the Atlantic Forest diversity and past ecosystem dynamics should consider multiple mechanisms operating at different spatial and temporal scales (Thomé et al. 2010).

The elucidating the process that acted in Atlantic forest is essential to understand the biodiversity present in this biome, and to conservation of lineages and species. Understanding the speciation process, the effects of climate oscilations will be important to estimate the consequence of global warming in this ecosystem. Predictions of ecological niche modeling to Brazil has indicated a decline of $80 \%$ of current distribution for half of the birds of the family Pipridae in Amazon and Atlantic Florest (Anciães \& Peterson, 2006). Niches paleoclimate modeling combined with molecular analysis has pointed to cases of recent population expansion from refuges or ecologically stable areas with high diversity and population structure in the Atlantic in response to environmental changes in the Quaternary Period: amphibians, lizards (Carnaval et al. 2009, Carnaval and Moritz 2008) and birds (Cabanne et al., 2008). Thus, the importance of the characterization of the distribution of the genetic diversity of threatened and non-threatened species is important to future conservation plans and politics efforts. 


\section{Acknowledgement}

This chapter aim to understand the principal evolutionary processes that are related to the diversification and maintenance of the Atlantic forest biodiversity.

The author thank to Fundação de Amparo a Pesquisa do Estado de São Paulo (FAPESP), Conselho Nacional de Pesquisa do Governo Brasileiro (CNPq), Coordenação de Aperfeiçoamento de Pessoal de Nível Superior (CAPES), Fundação de Amparo a Pesquisa do Estado de Minas Gerais (FAPEMIG) for given funding to develop these studies.

\section{References}

Brown, K.S. \& Ab'Saber, A.N. (1979). Ice-age forest refuges and evolution in Neotropics: correlation of paleoclimatoligical, geomorphological and pedological data with biological endemism. Paleoclimas, 5, 1-30.

Cabanne, G.S., D’Horta, F., Meyer, D., Myiaki, C. \& Silva, J.C.. (in press) Plumage and genetic variation in Dendrocolaptes platyrostris (Aves:Dendrocolaptidae): recent discontinuity between the south American open vegetation corridor and Atlantic Forest. Biological journal of Linnean Society

Cabanne, G.S., d'Horta, F.M., Sari, E.H., Santos, F.R. \& Miyaki, C.Y. 2008. Nuclear and mitochondrial phylogeography of the Atlantic forest endemic Xiphorhynchus fuscus (Aves: Dendrocolaptidae): biogeography and systematics implications. Molecular Phylogenetic and Evolution, 49, 760-773.

Cabanne, G.S., Santos, F. \& Miyaki, C.Y. (2007) Phylogeography and demographic history of Xiphorhynchus fuscus (Passeriformes: Dendrocolaptidae) in the southern Atlantic forest of Brazil and Argentina. Biological Journal of the Linnean Society, 91, 73- 84.

Carnaval, A.C. \& Moritz, C. (2008) Historical climate modeling predicts patterns of current biodiversity in the Brazilian Atlantic forest. Journal of Biogeography, 35, 1187-1201.

Carnaval, A.C., Hickerson, M.J., Haddad, C.F.B., Rodrigues, M.T., Moritz, C. (2009) Stability predicts genetic diversity in the Brazilian Atlantic Forest hotspot. Science 323, 785789.

Conservation International do Brasil, Fundação SOS Mata Atlântica, Fundação Biodiversitas, Instituto de Pesquisas Ecológicas, Secretaria do Meio Ambiente do Estado de São Paulo, SEMAD/Instituto Estadual de Florestas-MG (2000) Avaliação e acções prioritárias para a conservação da biodiversidade da Mata Atlântica e Campos Sulinos (ed. by Ministério do Meio Ambiente / Secretaria Nacional de Biodiversidade e Florestas). pp. 40. Brasília.

Costa, L.P. (2003) The historical bridge between the Amazon and the Atlantic forest of Brazil: a study of molecular phylogeography with small mammals. Journal of Biogeography, 30, 71-86

Costa, L.P., Leite, Y.L.R., da Fonseca, G.A.B. \& da Fonseca, M.T. (2000) Biogeography of South American forest mammals: endemism and diversity in the Atlantic forest. Biotropica, 32, 872-881.

D'Horta, F.M., Cabanne, G.S., Meyer, D. \& Miyaki,.C.Y. (2011). The genetic effects of Late Quaternary climatic changes over a tropical latitudinal gradient: diversification of an Atlantic Forest passerine. Molecular Ecology xxxx

Diniz-Filho, J. A. F., De Campos Telles, M. P., Bonatto, S. L., Eizirik, E., De Freitas, T. R. O., De Marco, P., Santos, F. R., Sole-Cava, A. \& Soares, T. N. (2008) Mapping the 
evolutionary twilight zone: molecular markers, populations and geography. Journal of Biogeography, 35, 753-763.

Grazziotin, F.G., Monzel, M., Echeverrigarauy, S. \& Bonato, S.L. (2006) Phylogeography of the Bothrops jararaca complex (Serpentes: Viperidae): past fragmentation and island colonization in the Brazilian Atlantic Forest. Molecular Ecology, 15, 3969-3982.

Gusmão Câmara, I. (2003). Brief history of conservation in the Atlantic forest. In: GalindoLeal C, Gusmão Câmara I, eds. The state of the hotspots: the Atlantic forest. Washington, DC: Island Press, 31-42.

Haffer, J. \& Prance, G.T. (2001) Climatic forcing in Amazonia during the Cenozoic: on the refuge theory of biotic differentiation. Amazoniana, 16, 579-607.

Haffer, J. (1969). Speciation in Amazonian birds. Science, 165, 131-131.

Hewitt, G.M. (1996). Some genetic consequences of ice ages, and their role in divergence and speciation. Biol. J. Linn. Soc. Lond., 58, 247-276.

Hunter, M.L. (1996) Fundamentals of Conservation Biology. Blackwell Science, Massachusetts.

Lacerda, D.R., Marini, M.A. \& Santos, F.R., (2007). Mitochondrial DNA corroborates the species distinctiveness of the Planalto (Thamnophilus pelzelni Hellmayr, 1924), the Sooretama (T. ambiguus Swainson, 1825) Slaty-antshrikes (Passeriformes: Thamnophilidae). Braz. J. Biol. 67, 873-882.

Lara, M.C., Geise, L. \& Schneider, C.J. (2005) Diversification of small mammals in the Atlantic forest of Brazil: testing the alternatives. In: Mammalian diversification: From Chromosomes to Phylogeography (A Celebration of the Career of James L. Patto) (eds Lacey EA, Myers P), pp. 311-335. University of California Press Berkeley, Los Angeles, London

Ledru, M.P. (1993) Late quaternary environmental and climatic changes in central Brazil. Quaternary Research, 39, 90-98.

Martins, F., Templeton, A R., Pavan, A. C., Kohlbach, B. C. \& MORGANTE, J. S. (2009) Phylogeography of the common vampire bat (Desmodus rotundus): Marked population structure, Neotropical Pleistocene vicariance and incongruence between nuclear and mtDNA markers. BMC Evolutionary Biology 9, 294

Miller, M.J., Bermingham, E., Klicka, J., Escalante, P. \& Winker, K.(2010) Neotropical birds show a humped distribution of within-population genetic diversity along a latitudinal transect. Ecology Letters, 13, 576-586

Moraes-Barros, N., Silva, J.A.B., Miyaki, C.Y. \& Morgante, J.S. (2006) Comparative phylogeography of the Atlantic forest endemic sloth (Bradypus torquatus) and the widespread three-toed sloth (Bradypus variegatus) (Bradypodidae, Xenarthra). Genetica, 126, 189-198.

Moritz, C., Patton, J.L., Schneider, C.J. \& Smith, T.B. (2000) Diversification of rainforest faunas: an integrated molecular approach. Annual Review of Ecology and Systematics, 31, 533-563.

Mustrangi, M.A. \& Patton, J.L. (1997). Phylogeography and systematics of the slender mouse opossum Marmosops (Marsupialia,Didelphidae). University of California Publications in Zoology 130: 1-86

Myers, N., Mittermeier, R.A. \& Mittermeier, C.G., Fonseca, G.A.B., Kent, J. (2000). Biodiversity hotpots for conservation priorities. Nature, 403, 853-858. 
Oliveira-Filho, A.T. \& Fontes, M.A. (2000). Patterns of floristic differentiation among Atlantic Forests in SOutheartern Brazil and the influence of the climate. Biotropica, 32, 793-810.

Patton, J.L., Silva, M.N.F. \& Malcolm, J.R. (1994) Gene genealogy and differentiation among arboreal spiny rats (Rodentia: Echimyidae) of the Amazon Basin: a test of the riverine barrier hypothesis. Evolution, 48, 1314-1323.

Pavan, A.C., Martins, F., Santos, F.R, Ditchfield, A. \& Redondo, R.A.F. (2011). Patterns of diversification in two species of short-tailed bats (Carollia Gray, 1838): the effects of historical fragmentation of Brazilian rainforests.Biological Journal of the Linnean Society, 102, 527-539

Pellegrino, K.C.M., Rodrigues, M.T., Waite, A.N., Morando, M., Yassuda, Y.Y. \& Sites, J.W. (2005). Phylogeography and specieslimits in the Gymnodactylus darwinii complex (Gekkonidae, Squamata): genetic structure coincides with river system in the Brazilian Atlantic Forest. Biological Journal of the Linnean Society 85, 13-26.

Pessoa, R.O. (2007) Sistemática e Biogeografia Histórica da Família Conopophagidae (Aves: Passeriformes): Especiação nas Florestas da América do Sul. Tese de Doutorado, Instituto de Biociências da Universidade de São Paulo, São Paulo.

Prado, D.E. \& Gibbs, P.E. (1993) Patterns of species distributions in the dry seasonal forests of South America. Annals of the Missouri Botanical Garden, 80, 902-927

Primack, R.B. \& Rodrigues, E. (2001) Biologia da Conseração. Midiograf, Londrina, Paraná.

Puorto G., Salomão M. G., Theakston, R.D.G., Thorpe, R.S., Warrell D.A. \& wuester W. (2001) Combining mitochondrial DNA sequences and morphological data to infer species boundaries: phylogeography of lanceheaded pitvipers in the Brazilian Atlantic forest, and the status of Bothrops pradoi (Squamata: Serpentes: Viperidae). Journal of. Evolutionary Biology. 14, 527-538.

Ricommini, C. \& Assumpção, M., (1999). Quaternary tectonics in Brazil. Episodes 22, 221-225.

Rosenzweig, M.L. (1995). Species Diversity in Space and Time. Cambridge University Press, Cambridge.

Rozzi R., Primack, R., Feinsinger, P., Dirzo, R. \& Massardo. F. (1998) qué es la biología de la conservación? Pg 35-58 In: Primack, R., Rozzi, R., Feinsinger, P., Dirzo, R. \& Massardo, F. Fundamentos de Conservación Biológica: Perspectivas latinoamericans. Fondo de cultura Económica México.

Siedchlag, A.C., Benozzati, M.L., Passoni, J.C. \& Rodrigues, M. T.(2010) Genetic tructure, phylogeny, and biogeography of Brazilian eyelid-less lizards of genera Calyptommatus and Nothobachia (Squamata, Gymnophthalmidae) as inferred from mitochondrial DNA sequences. Molecular Phylogenetics and Evolution, 56, 622630

Silva, S. M., Moraes-Barros, N., Ribas, C. C., Ferrand, N. \& Morgante, J. S.(in press). Brazilian Atlantic Forest Biogeography - complexity revealed by current knowledge. Biogeography

Simpson, B.B. (1979) Quaternary biogeography of the high montane regions of South America. In: The South American Herpetofauna: its Origin, Evolution, and Dispersal (ed. Duellman WE), pp. 157-188. Monograph of the Museum of Natural History, University of Kansas, Lawrence, Kansas. 
Smith, M.F. \& Patton, J.L. (1999) Phylogenetic relationships and the radiation of sigmodontine rodents in South America: evidence from cytochrome b. Journal of Mammalian Evolution, 6, 89-128.

Thomé, M.T.C, Zamudio, K.R., Giovanelli, J.G.R., Haddad, C.F.B., Baldissera, F.A. Jr \& Alexandrino, J. (2010) Phylogeography of endemic toads and post-Pliocene persistence of the Brazilian Atlantic Forest. Molecular Phylogenetics and Evolution ,55, 1018-1031

Vanzolini, P.E. \& Williams, E.E. (1970) South american anoles: the geographic differentiation and evolution of the Anolis chrysolepis species group (Sauria: Iguanidae). Arquivos de Zoologia, 19, 1-298.

Vellend, M. \& Geber, M.A. (2005). Connections between species diversity and genetic diversity. Ecol. Lett., 8, 767-781.

Vellend, M. (2003). Island Biogeography of genes and species. Am. Nat., 162, 358-365.

Willig, M.R., Kaufman, D.M. \& Stevens, R.D. (2003) Latitudinal gradients of biodiversity: patterns, process, scale and synthesis. Annual Review of Ecology. Evolution and Systematics, 34, 273-309. 


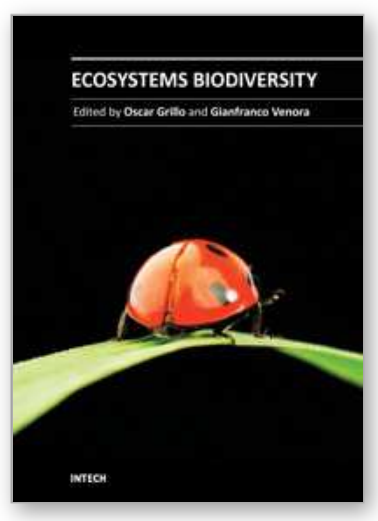

\author{
Ecosystems Biodiversity \\ Edited by PhD. Oscar Grillo
}

ISBN 978-953-307-417-7

Hard cover, 464 pages

Publisher InTech

Published online 16, December, 2011

Published in print edition December, 2011

Ecosystems can be considered as dynamic and interactive clusters made up of plants, animals and microorganism communities. Inevitably, mankind is an integral part of each ecosystem and as such enjoys all its provided benefits. Driven by the increasing necessity to preserve the ecosystem productivity, several ecological studies have been conducted in the last few years, highlighting the current state in which our planet is, and focusing on future perspectives. This book contains comprehensive overviews and original studies focused on hazard analysis and evaluation of ecological variables affecting species diversity, richness and distribution, in order to identify the best management strategies to face and solve the conservation problems.

\title{
How to reference
}

In order to correctly reference this scholarly work, feel free to copy and paste the following:

Gisele Pires Mendonça Dantas, Gustavo Sebastián Cabanne and Fabrício Rodrigues Santos (2011). How Past Vicariant Events Can Explain the Atlantic Forest Biodiversity?, Ecosystems Biodiversity, PhD. Oscar Grillo (Ed.), ISBN: 978-953-307-417-7, InTech, Available from: http://www.intechopen.com/books/ecosystemsbiodiversity/how-past-vicariant-events-can-explain-the-atlantic-forest-biodiversity-

\section{INTECH}

open science | open minds

\section{InTech Europe}

University Campus STeP Ri Slavka Krautzeka 83/A

51000 Rijeka, Croatia

Phone: +385 (51) 770447

Fax: +385 (51) 686166

www.intechopen.com

\section{InTech China}

Unit 405, Office Block, Hotel Equatorial Shanghai

No.65, Yan An Road (West), Shanghai, 200040, China

中国上海市延安西路65号上海国际贵都大饭店办公楼405单元

Phone: +86-21-62489820

Fax: $+86-21-62489821$ 
(C) 2011 The Author(s). Licensee IntechOpen. This is an open access article distributed under the terms of the Creative Commons Attribution 3.0 License, which permits unrestricted use, distribution, and reproduction in any medium, provided the original work is properly cited. 